\title{
Use of Chromium Oxide and Alkane Indicator Methods for Determination of Feed Intake for Grazing Sheep
}

\author{
Selcuk Altacli and Suphi Deniz \\ Department of Animal Nutrition and Nutritional Diseases, Faculty of Veterinary Medicine, University of Yuzuncu Yil, Van 65080, \\ Turkey
}

\begin{abstract}
This experiment was carried out to determine feed intake and digestibility of grazing sheep on pasture. A total of 14 animals randomly divided into two groups with seven animals each group were used in the experiment. Digestibility of pastures was determined using two types of markers-alkane $\left(\mathrm{C}_{32}-\mathrm{C}_{36}\right)$ and chromium oxide. Dry matter intake (DMI) was $717.22 \mathrm{~g} / \mathrm{d}$ based on chromium oxide method in the experiment, while according to alkane method, DMI was $965.93 \mathrm{~g} / \mathrm{d}$ and 1,051.07 g/d for $\mathrm{C}_{32}$ and $\mathrm{C}_{36}$, respectively. In conclusion, pastures met $74 \%-81 \%$ of crude protein (CP) and 57\%-61\% of energy requirements of lambs grazing on Yuzuncu Yil University pasture, who are mid-quality and 4-7 month-old with a $275 \mathrm{~g} / \mathrm{d}$ expected daily gain. It was calculated that when 628-693 g/d of barley is given, both CP and metabolizable energy (ME) requirements of animals can be met.
\end{abstract}

Key words: Pasture, chromium oxide, alkane, feed intake, digestibility, energy content.

\section{Introduction}

Ruminant rations basically comprise forage, energy feed, feed rich in protein and supplements, such as vitamins and minerals. The cheapest feed among the first three classes of feeds is forage. Forage is required for the secretion of enzymes needed for the rumen microflora of ruminants and for the promotion of rumen development, and is important in meeting animals' requirement of survival and efficiency rates, as well as vitamins and minerals. Moreover, an insufficient amount of forage in ruminant rations causes serious metabolic and digestive disorders [1]. Thus, using the highest possible amount of forage in ruminant rations is an important rule of a cost-effective ration.

However, since a feed consisting of forage alone does not often meet the animals' nutrient requirements, it becomes essential to provide animals with additional feeds rich in energy and protein to attain a proper and balanced nutrition. Since the enriched

Corresponding author: Selcuk Altacli, assistant professor, research fields: animal nutrition, feeds, in vivo and in vitro techniques. feeds cost more than the forage, the cost of rations increases proportionally with their degree of use [2].

Forage produced in Turkey is not sufficient for the needs of the animals. The reasons for this can be insufficient pasture areas, short vegetation period, low grass density and small number of cultivation areas for fodder crops [3]. If the need for quality forage, which is required for the animal husbandry in the country, is met, the use of forages that are poor in nutrients and rich in cellulose, such as stem, chaff and husk, will decrease and the efficiency obtained from the livestock unit will improve. While quality forage is a cheap source in animal feeding, it is also important, as it includes protein, fat and cellulose required for the development of the rumen microflora and fauna of the ruminants, it is rich in minerals and vitamins, improves the animal's performance, prevents many diet-related metabolic diseases and yields high quality animal products [4].

Pasture is the most economical source of feed for ruminant livestock. However, there is little research on the extent to which livestock farmers make use of pasture to feed their livestock, or on whether the 
nutritional requirements of livestock can be met by pasture. The nutritional requirements of livestock and the extent to which such needs are met by pasture should be determined, and concentrated feed supplements should be provided accordingly [5]. For this purpose, the amount and the degree of digestibility of the feed consumed by ruminants at pasture should be determined.

The principal nutritious fodder plant species, which are found in Turkey's pastures and could continue to exist if protected, include: Medicago spp., Melilotus spp., Poa spp., Lotus spp., Dactylis spp., Trifolium spp., Phalaris spp., Onobrychis spp., Festuca spp., Bromus spp., Agropyron spp. and Astragalus spp. [6].

To date, many marker-based methods have been developed, in an attempt to determine the feed consumption of livestock grazing on pasture and the digestibility of the feed [7-13]. Among the most common markers are lignin as an internal marker and chromium oxide (chromium sesquioxide) as an external marker. Furthermore, alkanes, also known as odd- and even-chain hydrocarbons in the cuticular wax layer of plants, have also recently been used as markers in nutritional studies. The alkane marker technique is a double marker technique based on the ratio of odd-chain alkanes to even-chain alkanes in feces. The alkane marker technique is mainly employed in studies on feed consumption and digestibility in relation to livestock fed predominantly with forage and grazed on pasture.

The purpose of this study was to determine, by means of markers, such as chromium oxide and alkane, the amount of feed consumption by sheep grazing on pasture and the digestibility of the feed consumed, and thereby identify the amount of nutrients consumed by livestock on pasture, as well as the amount of energy intake and the amount of additional feed needed.

\section{Materials and Methods}

\subsection{Animal Materials}

This study was carried out simultaneously in two trials, which were based on the chromium oxide marker method and the alkane marker method. Fourteen Morkaraman (breed) rams, 1.5 years old and having a similar live weight, were used in the study. The animals were randomly divided into two groups consisting of seven rams for each trial. The average live weights of the groups were $38.77 \pm 2.86 \mathrm{~kg}$ in the chromium group and $39.63 \pm 2.78 \mathrm{~kg}$ in the alkane group.

\subsection{Pasture Localization and Characteristics}

The animals were grazed on pasture in the campus of the Yuzuncu Yil University. Zeve Campus of the Van Yuzuncu Yil University, in which this study is conducted, is in the closed basin of Lake Van, and is phytogeographically located in the Iran-Turan region [14]. It has a continental climate and is included in the climate zone with 3-4 months of drought. Botanical composition of the pastures of the Zeve Campus of Yuzuncu Yil University consists of the members of Lamiaceae family. In a study conducted in the area, 12 genera and 31 taxa of Lamiaceae family were detected [15]. While the genus Salvia was ranked the first with 12 taxa, Ajuga and Ziziphora were ranked the second and the third with three taxa each, and other genera were represented with one and two taxa. The pasture chemical composition is as percentage of dry matter (DM\%): organic matter (OM) 88.81\%, crude protein (CP) $14.14 \%$, crude fiber (CF) $36.86 \%$ and nitrogen-free extract (NFE) $35.97 \%$.

\subsection{Experimental Design}

The grazing took place between 6:00 am and 11:00 am and between 15:00 pm and 20:00 pm. The animals were watered using the troughs in the open shed area, where they were allowed to rest on the way from the pasture. Herb samples (no less than 100 pieces) were taken from the pasture using the hand picking method [13, 16, 17]. Herb samples were collected from the locations, where the animals 
grazed for a period of $9 \mathrm{~d}$, starting from one day prior to the period in which the fecal samples were collected. Herb sample collection was carried out after observing the grazing behavior of the animals and the herbs they ate. In order to ensure that the nutrient content of the herbs eaten by the animals and the samples collected were as similar as possible, the animals were observed for $1 \mathrm{~h}$ every day and samples were collected from the herbs they consumed. The samples were combined daily.

The version modified by Marten and Barnes [18] of the two-stage method reported by Tilley and Terry [19] was employed in the trial. Using the values obtained from this technique, the feed consumption of the animals was determined using the chromium oxide and alkane methods.

The herbs with chromium, bound to the neutral detergent fiber (NDF) in the chromium marker method, were given to the animals with one pellet given in the morning and one pellet in the evening (8:00 am and 16:00 pm). So, herbs containing $2 \mathrm{~g}$ of chromium were given daily to the animals, starting from the beginning of habituation period. The sampling process took $8 \mathrm{~d}$. Fecal samples were collected twice a day. The fecal samples collected were combined for each animal, resulting in seven fecal samples in total. Chromium analyses of the forages picked up from the pasture and of the fecal samples collected were conducted in accordance with Williams et al. [20].

In the alkane trial, commercial alkane capsules, designed for use in the rumen of sheep with a live weight of 25-80 kg, were used. Each alkane capsule contains $1 \mathrm{~g}$ of n-dotriacontane $\left(\mathrm{C}_{32}\right)+1 \mathrm{~g}$ n-hexatriacontane $\left(\mathrm{C}_{36}\right)$, and the capsules release 50 $\mathrm{mg}$ of $\mathrm{C}_{32}$ and $50 \mathrm{mg}$ of $\mathrm{C}_{36}$ into the rumen daily. In this method, fecal samples were collected from all animals twice a day at 8:00 am and 16:00 pm, starting from $8 \mathrm{~d}$ after the capsules had been given to the animals. This continued for a period of $8 \mathrm{~d}$. The preparation of the forage and fecal samples for alkane analysis and the reading thereof on the gas chromatography device were done in accordance with the method reported by Unal [8].

In the chromium oxide method, the chromium (Cr) concentration in the samples and standard solutions was calculated using the following Eq. (1) with some modifications [21]:

$$
\mathrm{Cr} \%=\frac{C(\mathrm{mg} / \mathrm{mL}) \times V(\mathrm{~mL})}{\text { sample amount }(\mathrm{mg})}
$$

where, $C=$ sample concentration $(\mathrm{mg} / \mathrm{mL}) ; V=$ standard solution volume $(\mathrm{mL})$.

In the same method, forage consumption was determined using the following Eq. (2) [22-24]:

Forage concumption $=$

$$
\frac{\text { amount of daily fecal output (g) }}{1-\text { in vitro dry matter digestibility (\%) }}
$$

In the chromium oxide and alkane methods, fecal excretion was calculated using the following Eq. (3) [25-27]:

Fecal excretion $=$

indicator amount of daily intake (g/day)

indicator amount of feces (g/g DM)

In the alkane method, forage consumption was calculated using the following Eq. (4) [5, 8]:

$$
\text { DMIE }=\frac{\frac{\mathrm{F}_{33}}{\mathrm{~F}_{32}} \times \mathrm{DZ}_{32}}{\mathrm{Fo}_{33}-\frac{\mathrm{F}_{33}}{\mathrm{~F}_{32}} \times \mathrm{Fo}_{32}}
$$

where, DMIE = estimated intake of dry matter $(\mathrm{kg}$ $\mathrm{DM} /$ day); $\mathrm{Fo}_{33}, \mathrm{~F}_{33}=$ amount of alkane $\mathrm{C}_{33}$ in forage and feces (mg/kg DM); $\mathrm{Fo}_{32}, \mathrm{~F}_{32}=$ amount of alkane $\mathrm{C}_{32}$ in forage and feces (mg/kg DM); $\mathrm{DZ}_{32}=$ amount of alkane $\mathrm{C}_{32}$ given externally in a certain dose (0.05 g/day). Besides, $\mathrm{C}_{36}$ can also be used instead of $\mathrm{C}_{32}$.

In the chromium oxide and alkane methods, the digestibility of the forage and nutrients in the forage were calculated using the following Eqs. (5) and (6) [2, 28]: 


$$
\begin{aligned}
& \text { Digestibility of the forage }(\%)= \\
& \text { indicator in feces }(\%)-\text { indicator in forage }(\%) \\
& \text { indicator in feces }(\%) \\
& \text { Digestibility of any nutrient (D\%) in the forage: } \\
& \mathrm{D} \%=100 \%-\left(\frac{\text { indicator in forage }(\%)}{\text { indicator in feces }(\%)}\right. \\
& \left.\times \frac{\text { any nutrient in feces }(\%)}{\text { any nutrient in forage }(\%)}\right) \times 100
\end{aligned}
$$

In the chromium oxide and alkane methods, energy contents (Mcal/kg DM) of the forage were calculated using the following Eq. (7)-(9) [29, 30]:

Digestible energy (DE; Mcal/kg DM)

$$
=\mathrm{OMD} \% \times 0.04409
$$

Metabolizable energy (ME; Mcal/kg DM)

$$
=\mathrm{DE} \times 0.82
$$

Net energy lactation $\left(\mathrm{NE}_{\mathrm{L}} ; \mathrm{Mcal} / \mathrm{kg} \mathrm{DM}\right)$

$$
=\mathrm{OMD} \% \times 0.0245-0.12
$$

Using the daily average amount of dry matter intake by animals at pasture, the amount of $\mathrm{CP}$ and $\mathrm{ME}$ intake by the animals from the pasture was calculated. Taking into account the needs of animals at 4-7 months of age (finishing lambs), which should gain $275 \mathrm{~g}$ of live weight per day [31], the required amount of feed to be given to the animals in addition to which they foraged at pasture, were calculated.

DM, ash, CP and ether extract (EE) analyses of the feces obtained from the animals fed with forage through the chromium oxide and alkane methods were conducted in accordance with the Weende analysis system [32] for dried samples, and the CF, NDF, acid detergent fiber (ADF) and acid detergent lignin (ADL) analyses were conducted in accordance with Van Soest and Robertson [33].

\subsection{Statistical Analysis}

The average standard deviation of the data and other descriptive statistics were obtained using the Proc Means command of SAS/STAT 9.3 User's Guide version. The Proc GLM command of SAS was used to conduct chance variance analysis of the data [34].

\section{Results and Discussion}

\subsection{Nutrient Values of the Pasture Herbs}

The average nutrient values of the forage herbs consumed by the animals at the sampling period (June 14-22, 2011) (Table 1) are as follows: wet DM 40.13\%, ash 11.19\%, OM 88.81\%, CP 14.14\%, EE 1.83\%, NDF 54.89\%, ADF 31.67\%, ADL 5.63\%, CF $36.86 \%$ and NFE 35.97\%. In vitro dry matter digestibility was found to be $66.47 \%$. In the study conducted in the pastures of Altindere State Farm at 2-week intervals, starting from the 2nd week of May, Karsli et al. [35] obtained the following findings regarding the nutrient contents of the forage samples collected from open and protected $1 \mathrm{~m}^{2}$ areas during the 3rd sampling period (June 15), which corresponds to the sampling period of this study: DM 57.11\% and 53.34\%, ash $8.07 \%$ and $8.47 \%$, OM $91.93 \%$ and 91.53\%, CP 10.63\% and 10.21\%, NDF 67.64\% and 67.35\%, ADF 38.33\% and 39.54\%, respectively. They found that in vitro dry matter digestibility was $55.15 \%$ and $52.60 \%$. The forage quality determined by this study is generally higher than the values found by Karsli et al. [35] using the pastures of Altındere State Farm. The main reason for this difference is that the sampling was done based on the selection of the herbs consumed by the animals at pasture. Indeed, Lopez-Guerrero [25] reports that in a process of forage sampling in the pasture, the nutrient content of the samples collected by picking up all herbs in a given area will differ from the nutrient content of the samples collected by picking up certain herbs. The ash, $\mathrm{CP}, \mathrm{NDF}, \mathrm{ADF}$ and in vitro dry matter digestibility (IVDMD) values in the forage collected by cutting the herbs in a given area in the said study were found to be $9.99 \%, 10.61 \%, 53.69 \%, 29.79 \%$ and $66.83 \%$, respectively. The same parameters in the hand picking method were found to be $9.15 \%, 14.57 \%, 44.97 \%$, $25.67 \%$ and $75.77 \%$, respectively. 
Table 1 Crude nutrient contents (DM\%) of the forage samples used in the study.

\begin{tabular}{lllllllllll}
\hline Feed materials & Wet DM & Ash & OM & CP & EE & NDF & ADF & ADL & CF & NFE \\
\hline Day 1 & 38.37 & 10.40 & 89.60 & 13.05 & 1.78 & 52.00 & 26.97 & 3.90 & 42.63 & 32.14 \\
Day 2 & 38.10 & 9.52 & 90.48 & 15.23 & 3.09 & 51.07 & 30.09 & 6.17 & 43.67 & 28.48 \\
Day 3 & 42.33 & 11.65 & 88.35 & 15.74 & 1.83 & 50.71 & 27.79 & 4.65 & 34.40 & 36.38 \\
Day 4 & 37.80 & 11.15 & 88.85 & 13.07 & 1.65 & 59.72 & 30.92 & 5.80 & 34.94 & 39.19 \\
Day 5 & 39.02 & 10.43 & 89.57 & 13.65 & 1.61 & 60.63 & 34.66 & 6.40 & 37.05 & 37.26 \\
Day 6 & 41.38 & 10.63 & 89.37 & 15.79 & 2.05 & 52.27 & 32.65 & 5.76 & 33.22 & 38.31 \\
Day 7 & 43.04 & 12.46 & 87.54 & 11.99 & 1.73 & 56.93 & 34.72 & 5.17 & 35.90 & 37.92 \\
Day 8 & 36.63 & 12.34 & 87.66 & 14.74 & 1.60 & 57.49 & 33.47 & 6.67 & 39.99 & 31.33 \\
Day 9 & 44.51 & 12.16 & 87.84 & 14.00 & 1.14 & 53.24 & 33.76 & 6.13 & 29.98 & 42.73 \\
\hline Mean & 40.13 & 11.19 & 88.81 & 14.14 & 1.83 & 54.89 & 31.67 & 5.63 & 36.86 & 35.97 \\
\hline
\end{tabular}

Wet DM: wet dry matter; OM: organic matter; CP: crude protein; EE: ether extract; NDF: neutral detergent fiber; ADF: acid detergent fiber; ADL: acid detergent lignin; CF: crude fiber; NFE: nitrogen-free extract.

Table 2 Alkane contents (mg/kg DM) of forages used in the study.

\begin{tabular}{llll}
\hline \multirow{2}{*}{ Feed material } & \multicolumn{3}{c}{ Alkane contents (mg/kg DM) } \\
\cline { 2 - 4 } & $\mathrm{C}_{32}$ & $\mathrm{C}_{33}$ & $\mathrm{C}_{36}$ \\
\hline Forage (pasture) & 9.96 & 41.30 & 3.82 \\
\hline
\end{tabular}

Table 3 Average DM consumption values (g/d) determined by chromium oxide and alkane methods.

\begin{tabular}{lllllll}
\hline Methods & $\begin{array}{l}\text { Chromium oxide } \\
(n=7)\end{array}$ & $\begin{array}{l}\text { Morning } \\
(n=7)\end{array}$ & $\begin{array}{l}\text { Evening } \\
(n=7)\end{array}$ & & $\begin{array}{l}\text { Morning } \\
(n=7)\end{array}$ & $\begin{array}{l}\text { Evening } \\
(n=7)\end{array}$ \\
\hline $\begin{array}{l}\text { Average dry matter } \\
\begin{array}{l}\text { consumption } \\
(\bar{x} \pm S \bar{X})\end{array}\end{array}$ & $717.22 \pm 54.75^{\mathrm{b}}$ & $961.86 \pm 43.65^{\mathrm{a}}$ & $970.00 \pm 48.03^{\mathrm{a}}$ & & $1,044.86 \pm 42.45^{\mathrm{a}}$ & $1,057.29 \pm 45.37^{\mathrm{a}}$ \\
\hline
\end{tabular}

${ }^{\mathrm{a}, \mathrm{b}}$ Differences between the averages with a different letter in the same row are significant $(P<0.05)$.

\subsection{Alkane Method}

Amounts of alkane $\mathrm{C}_{32}, \mathrm{C}_{33}$ and $\mathrm{C}_{36}$ in the forage from the pasture in this study were found to be 9.96, 41.30 and $3.82 \mathrm{mg} / \mathrm{kg} \mathrm{DM}$, respectively (Table 2). The values found for $\mathrm{C}_{32}$ and $\mathrm{C}_{33}$ by Karademir and Unal [5] are $3.27 \mathrm{mg} / \mathrm{kg}$ DM and $19.79 \mathrm{mg} / \mathrm{kg} \mathrm{DM}$, respectively. They could not determine the amount of $\mathrm{C}_{36}$. In a study by Berry et al. [36], they determined that the amounts of $\mathrm{C}_{31}, \mathrm{C}_{32}$ and $\mathrm{C}_{33}$ in a mixture of feed consisting of $51 \%$ grass silage, $39 \%$ corn silage and 10\% dried fodder were 121, 4 and $44 \mathrm{mg} / \mathrm{kg} \mathrm{DM}$, but they could not determine the amount of $\mathrm{C}_{36}$.

In the alkane method, the daily dry matter intake by the animals was found to be $961.86 \pm 43.65 \mathrm{~g}$ in the morning samples and $970 \pm 48.3 \mathrm{~g}$ in the evening samples (965.93 $\pm 31.20 \mathrm{~g}$ in average) for $\mathrm{C}_{32}$, and
$1,044.86 \pm 42.45 \mathrm{~g}$ in the morning samples and $1,057.29 \pm 45.37 \mathrm{~g}$ in the evening samples $(1,051.07 \pm$ $29.90 \mathrm{~g}$ in average) for $\mathrm{C}_{36}$ (Table 3). Considering that the average live weight of the animals used in this method is $39.63 \pm 2.78 \mathrm{~kg}$, the amount of dry matter intake by them was found to be $2.43 \%$ to $2.67 \%$ of their live weight. These results are consistent with the amount of dry matter intake required for fatlings, which is $2.5 \%$ of the live weight.

\subsection{Chromium Oxide Method}

In the chromium oxide method, the daily forage consumption by the animals was found to be $717.22 \pm$ $54.75 \mathrm{~g}$ (Table 3). Considering that the average live weight of the animals used in this method is $38.77 \pm$ $2.86 \mathrm{~kg}$, the amount of dry matter intake by them was found to be $1.85 \%$ of their live weight. Using the same 
method, Ferret et al. [37] found that the daily forage consumption (657.71 g DM) by the sheep (63.20 \pm 1.5 $\mathrm{kg}$ ) fed with a mixture of meadow, grass and dried alfalfa was $1.04 \%$ of their live weight. Parker et al. [38] report that the dry matter intake by the sheep with a live weight of $46.6 \mathrm{~kg}$ consuming $1.589 \mathrm{~g} / \mathrm{d}$ of forage consisting of meadow grass and white clover is $3.41 \%$ of their live weight. In a study conducted on pregnant Border-Leicester/Merino sheep with an average live weight of $55.5 \mathrm{~kg}$, Dove et al. [39] found that the organic matter intake (1.349 g) by the sheep was $2.43 \%$ of their live weight. Momont et al. [40] found that the daily dry matter intake by Hampshire hoggets with an average live weight of $53 \mathrm{~kg}$ was $1.033 \mathrm{~g}$ (5.13\% of their live weight). The differences between the data obtained by the above mentioned studies are associated with the varying digestibility of the forage or feed mixtures used. In the area of animal nutrition, it is already known that highly digestible feeds are consumed more. The high level of consumption of the mixture of meadow grass and white clover given by Parker et al. [38] to the animals (3.41\% of their live weight) is accounted for the fact that this mixture's digestibility is $72.48 \%$.

\subsection{CP and Energy Intake from Pasture and the Need for Additional Feeding}

In the chromium oxide and alkane method, the nutrient digestibility and energy content of the forage samples were given in Table 4. Ferret et al. [37] found that dry matter digestibility of the mixture of meadow grass and dried alfalfa given to sheep was $62.19 \%$ in the chromium oxide method. Parker et al. [38] calculated the average dry matter digestibility of the mixture of meadow grass and white clover given to sheep to be $72.48 \%$. In a study conducted on pregnant Border-Leicester/Merino sheep with an average live weight of $55.5 \mathrm{~kg}$, Dove et al. [39] found that the organic matter digestibility of forage was $75.6 \%$. In their study on castrated rams, Elwert et al. [41] noted that the organic matter digestibility of forage consisting of clover and ground wheat given daily to the rams with a live weight of $55.5 \mathrm{~kg}$ was $72.50 \%$. The value of metabolic energy of clover was calculated to be $2.06 \mathrm{Mcal} / \mathrm{kg} \mathrm{DM}$ by the same researchers. The gross energy (GE), $\mathrm{ME}$ and $\mathrm{NE}_{\mathrm{L}}$ values

Table 4 Nutrient digestibility (\%) and energy contents (Mcal/kg DM) of feeds determined by chromium oxide and alkane methods.

\begin{tabular}{|c|c|c|c|c|c|c|}
\hline \multirow{3}{*}{ Contents } & \multirow{2}{*}{\multicolumn{2}{|c|}{ Chromium oxide }} & \multicolumn{4}{|c|}{ Alkane } \\
\hline & & & \multicolumn{2}{|c|}{$\mathrm{C}_{32}$} & \multicolumn{2}{|r|}{$\mathrm{C}_{36}$} \\
\hline & $n$ & $\bar{x} \pm S x$ & $n$ & $\bar{x} \pm S \bar{x}$ & $n$ & $\bar{x} \pm S x$ \\
\hline DMD & 7 & $65.20 \pm 0.04$ & 14 & $68.40 \pm 1.43$ & 14 & $65.13 \pm 1.60$ \\
\hline OMD & 7 & $69.59 \pm 0.36$ & 14 & $72.48 \pm 1.23$ & 14 & $69.63 \pm 1.36$ \\
\hline CPD & 7 & $66.08 \pm 1.28$ & 14 & $69.02 \pm 1.26$ & 14 & $65.82 \pm 1.39$ \\
\hline EED & 7 & $24.30 \pm 2.31$ & 14 & $26.21 \pm 4.75$ & 14 & $26.95 \pm 5.55$ \\
\hline NDFD & 7 & $62.38 \pm 0.32$ & 14 & $66.71 \pm 1.57$ & 14 & $63.26 \pm 1.75$ \\
\hline ADFD & 7 & $57.80 \pm 0.33$ & 14 & $65.76 \pm 1.50$ & 14 & $62.21 \pm 1.68$ \\
\hline GE & 7 & $3.90 \pm 0.00$ & 14 & $3.90 \pm 0.00$ & 14 & $3.90 \pm 0.00$ \\
\hline $\mathrm{DE}$ & 7 & $3.07 \pm 0.02$ & 14 & $3.20 \pm 0.05$ & 14 & $3.07 \pm 0.06$ \\
\hline ME & 7 & $2.52 \pm 0.01$ & 14 & $2.62 \pm 0.04$ & 14 & $2.52 \pm 0.05$ \\
\hline $\mathrm{NE}_{\mathrm{L}}$ & 7 & $1.58 \pm 0.01$ & 14 & $1.66 \pm 0.03$ & 14 & $1.59 \pm 0.03$ \\
\hline
\end{tabular}

DMD: dry matter digestibility; CPD: crude protein digestibility; EED: ether extract digestibility; NDFD: neutral detergent fiber digestibility; ADFD: acid detergent fiber digestibility; GE: gross energy; DE: digestible energy; ME: metabolizable energy; $\mathrm{NE}_{\mathrm{L}}$ : net energy lactation.

Differences between the averages in the same row are insignificant $(P>0.05)$. 
Table 5 Amount of CP and ME intake from pasture and amount of barley supplement required to be given (g).

\begin{tabular}{|c|c|c|c|c|c|c|c|c|c|c|c|}
\hline \multirow[t]{2}{*}{ Methods } & \multirow{2}{*}{$\begin{array}{l}\text { Pasture forage } \\
\text { (g) }\end{array}$} & \multicolumn{2}{|c|}{$\begin{array}{l}\mathrm{CP} \text { and ME } \\
\text { content of forage }\end{array}$} & \multicolumn{2}{|c|}{$\begin{array}{l}\text { Amount of } \mathrm{CP} \text { and } \mathrm{ME} \\
\text { intake from forage }\end{array}$} & \multicolumn{2}{|c|}{$\begin{array}{c}\text { CP and ME requirement } \\
\text { of livestock } \\
\text { (NRC, 1985) [31] }\end{array}$} & \multicolumn{2}{|c|}{$\mathrm{CP}$ and ME deficit } & \multicolumn{2}{|c|}{$\begin{array}{l}\text { Barley supplement } \\
\text { requirement (g) }\end{array}$} \\
\hline & & $\begin{array}{l}\text { CP } \\
(\mathrm{g} / \mathrm{kg} \mathrm{DM})\end{array}$ & $\begin{array}{l}\text { ME } \\
(\text { Mcal/kg DM) }\end{array}$ & CP (g) & ME (Mcal) & CP (g) & ME (Mcal) & CP (g) & ME (Mcal) & For CP & For ME \\
\hline $\begin{array}{l}\text { Chromium } \\
\text { oxide }\end{array}$ & $717 \pm 55^{b}$ & 141.4 & 2.52 & $\begin{array}{l}101 \pm 8^{b} \\
(55 \%)\end{array}$ & $\begin{array}{l}1.81 \pm 0.14^{b} \\
(41 \%)\end{array}$ & 185 & 4.4 & $84 \pm 8^{a}$ & $2.59 \pm 0.14^{\mathrm{a}}$ & $702 \pm 65^{\mathrm{a}}$ & $947 \pm 50^{\mathrm{a}}$ \\
\hline $\begin{array}{l}\mathrm{C}_{32} \\
\text { morning }\end{array}$ & $962 \pm 44^{\mathrm{a}}$ & 141.4 & 2.66 & $\begin{array}{l}136 \pm 6^{\mathrm{a}} \\
(74 \%)\end{array}$ & $\begin{array}{l}2.56 \pm 0.14^{\mathrm{a}} \\
(58 \%)\end{array}$ & 185 & 4.4 & $49 \pm 6^{b}$ & $1.84 \pm 0.14^{\mathrm{b}}$ & $412 \pm 52^{\mathrm{b}}$ & $672 \pm 139^{\mathrm{b}}$ \\
\hline $\begin{array}{l}\mathrm{C}_{32} \\
\text { evening }\end{array}$ & $970 \pm 48^{\mathrm{a}}$ & 141.4 & 2.58 & $\begin{array}{l}137 \pm 7^{\mathrm{a}} \\
(74 \%)\end{array}$ & $\begin{array}{l}2.50 \pm 0.15^{\mathrm{a}} \\
(57 \%)\end{array}$ & 185 & 4.4 & $48 \pm 7^{b}$ & $1.90 \pm 0.15^{\mathrm{b}}$ & $402 \pm 57^{\mathrm{b}}$ & $693 \pm 54^{\mathrm{b}}$ \\
\hline $\begin{array}{l}\mathrm{C}_{36} \\
\text { morning }\end{array}$ & $1,045 \pm 43^{\mathrm{a}}$ & 141.4 & 2.56 & $\begin{array}{l}148 \pm 6^{\mathrm{a}} \\
(80 \%)\end{array}$ & $\begin{array}{l}2.67 \pm 0.14^{\mathrm{a}} \\
(61 \%)\end{array}$ & 185 & 4.4 & $37 \pm 6^{\mathrm{b}}$ & $1.73 \pm 0.14^{\mathrm{b}}$ & $313 \pm 50^{\mathrm{b}}$ & $628 \pm 53^{b}$ \\
\hline $\begin{array}{l}\mathrm{C}_{36} \\
\text { evening } \\
\end{array}$ & $1,057 \pm 45^{\mathrm{a}}$ & 141.4 & 2.47 & $\begin{array}{l}150 \pm 6^{\mathrm{a}} \\
(81 \%)\end{array}$ & $\begin{array}{l}2.61 \pm 0.13^{\mathrm{a}} \\
(59 \%)\end{array}$ & 185 & 4.4 & $36 \pm 6^{\mathrm{b}}$ & $1.79 \pm 0.13^{\mathrm{b}}$ & $298 \pm 54^{\mathrm{b}}$ & $651 \pm 49^{\mathrm{b}}$ \\
\hline
\end{tabular}

${ }^{\mathrm{a}, \mathrm{b}}$ Differences between the averages with a different letter in the same column are significant $(P<0.05)$ 
of the forages used by Smit et al. [11] were found to be $1.83,1.05$ and 0.6 , respectively. The $\mathrm{NE}_{\mathrm{L}}$ value calculated in a study by Berry et al. [36] was found to be $1.39 \mathrm{Mcal} / \mathrm{kg} \mathrm{DM}$.

The amount of CP and ME intake from pasture and the required amount of barley supplement to be given in addition to the forage in the pasture are given in Table 5. As can be seen in Table 5, pasture grass intake detected via chromium oxide and alkane methods was 717.22, 961.86, 970, 1,044.86 and $1,057.29 \mathrm{~g}(P<0.05)$ in chromium oxide, $\mathrm{C}_{32}$ morning, $\mathrm{C}_{32}$ evening, $\mathrm{C}_{36}$ morning and $\mathrm{C}_{36}$ evening groups, respectively. The values for the alkanes were found to be similar to each other and higher than the chromium oxide group. In the calculations performed considering the $\mathrm{CP}$ and $\mathrm{ME}$ values of the pasture grass and the animals' requirements of $\mathrm{CP}$ and $\mathrm{ME}$, it was found that CP requirement was 55\%, 74\%, $74 \%$, $80 \%$ and $81 \%$ in chromium oxide, $\mathrm{C}_{32}$ morning, $\mathrm{C}_{32}$ evening, $\mathrm{C}_{36}$ morning and $\mathrm{C}_{36}$ evening groups, respectively; whereas $\mathrm{ME}$ requirement was $41 \%, 58 \%$, $57 \%, 61 \%$ and $59 \%$ in the same order. It was suggested that the additional need of $\mathrm{CP}$ and $\mathrm{ME}$ should be provided by additional feeding. In calculations performed to meet the additional needs of $\mathrm{CP}$ and ME, as the need for ME was higher, meeting this need was considered essential. Therefore, when barley (rank the 31st), which contains $11.9 \% \mathrm{CP}$ and $2.74 \mathrm{Mcal} / \mathrm{kg}$ energy, was used, barley supplement required for the chromium oxide, $\mathrm{C}_{32}$ morning, $\mathrm{C}_{32}$ evening, $\mathrm{C}_{36}$ morning and $\mathrm{C}_{36}$ evening groups were 947, 672, 693, 628 and $651 \mathrm{~g}$, respectively.

\section{Conclusions}

Considering that in the alkane method, the dry matter intake by the animals was $2.43 \%$ to $2.67 \%$ of their live weight. It can be seen that the dry matter intake values obtained by this method are more significant than the values obtained in the chromium oxide method (1.85\% of live weight). Therefore, it was calculated that a barley supplement of $628 \mathrm{~g}$ to
693 g per day would be sufficient to meet the CP and ME requirements of lambs at 4-7 months of age grazed in the pasture of Yüzüncü Yil University Campus, a medium quality pasture, and to ensure a live weight gain of $275 \mathrm{~g}$.

As capsules with controlled release were used in the alkane method, a fixed indicator concentration in the excrement was achieved, and feed intake values were consistent with the classical knowledge on animal feeding. In the chromium oxide method, as chromium oxide pellets were added to the rumen twice a day, a fixed indicator concentration in the excrement could not be achieved, and the feed intake values of the animals were lower.

It is obvious that the far-reaching influence of such studies conducted in a given pasture will be limited on the grounds that the nutritional quality of pastures is affected by factors, such as the vegetative composition, vegetation period, precipitation and mode of grazing, and that the mode of yield and level of yield of animals grazed in the pasture vary. For this reason, practical results can be reached and applied only on the basis of the data from numerous studies.

\section{References}

[1] Kara, M. A., and Deniz, S. 2005. "The Determination of Energy Content of Dried Grass Hay Produced Van Region in Vitro and in Sacco Techniques.” Presented at the 3rd National Animal Nutrition Congress, September 07-10, 2005, Adana, Turkey. (in Turkish)

[2] Sari, M., Bolat, D., Cerci, I. H., Onol, A. G., Deniz, S., Azman, M. A., Sahin, K., Güler, T., Seven-Tatli, P., Karsli, M. A., Sahin, N., Nursoy, H., Ciftci, M., and Bingol, N. T. 2008. Animal Nutrition and Nutritional Diseases. Malatya, Turkey: Medipres Matbaacilik. (in Turkish)

[3] Gungor, T., Basalan, M., and Akdogan, I. 2008. “The Determination of Nutrient Contents and Metabolizable Energy Levels of Some Roughages Produced in Kirikkale Region.” Veterinary Journal of Ankara University 55: 111-5. (in Turkish)

[4] Alcicek, A., Kilic, A., Ayhan, V., and Ozdogan, M. 2010. "Roughage Production and Problems in Turkey." Presented at the 8th Agricultural Engineering Technical Congress, January 11-15, 2010, Ankara, Turkey. (in 
Turkish)

[5] Karademir, G., and Unal. Y. 2008. "Estimation of Feed Intake and Digestibility by Sheep Fed at Various Levels of Concentrate, Using Alkane Indicator Technique.” Ph.D. thesis, Health Sciences Institute, University of Kafkas, Kars, Turkey. (in Turkish)

[6] Balabanli, C., Ogurlu, I., Unal, Y., and Süel, H. 2006. "Nutrition Types of Some Wild Animals Living in Forest Pastures.” Journal of Agriculture Faculty of Selcuk University 39 (20): 71-6. (in Turkish)

[7] Malossini, F., Bovolenta, S., Piasentier, E., Piras, C., and Martilotti, F. 1996. "Comparison of n-Alkanes and Chromium Oxide Methods for Estimating Herbage Intake by Grazing Dairy Cows.” Animal Feed Science Technology 61: 155-65.

[8] Unal, Y. 1998. "Estimation of Feed Intake by Housed Dairy Cows Using Alkanes and Near Infrared Reflectance Spectroscopy.” Ph.D. thesis, Division of Agriculture and Horticulture, School of Biological Sciences, University of Nottingham, Sutton Bonington, Loughborough, Leicestershire, United Kingdom.

[9] Hendricksen, R. E., Reich, M. M., Roberton, R. F., Reid, D. J., Gazzola, C., Rideout, A., and Hill, R. A. 2002. "Estimating the Voluntary Intake and Digestibility of Buffel-Grass and Lucerne Hays Offered to Brahman-Cross Cattle Using n-Alkanes.” Animal Science 74 (3): 567-77.

[10] Molina, D. O., Matamoros, I., and Pell, A. N. 2004. "Accuracy of Estimates of Herbage Intake of Lactating Cows Using Alkanes: Comparison of Two Types of Capsules.” Animal Feed Science and Technology 114: 241-60.

[11] Smit, H. J., Taweel, H. Z., Tas, B. M., Tamminga, S., and Elgersma, A. 2005. "Comparison of Techniques for Estimating Herbage Intake of Grazing Dairy Cows.” J. Dairy Sci. 88 (5): 1827-36.

[12] Olivan, M., Ferreira, L. M. M., Celeya, R., and Osoro, K. 2007. "Accuracy of the n-Alkane Technique for Intake Estimates in Beef Cattle Using Different Sampling Procedures and Feeding Levels.” Livestock Science 106 (1): 28-40.

[13] De Oliveira, D. E., De Mederios, S. R., Tedeschi, L. O., Aroeira, J. J. M., and Da Silva, S. C. 2007. "Estimating Forage Intake of Lactating Dual-Purpose Cows Using Chromium Oxide and n-Alkanes as External Markers.” Scientia Agricola 64 (2): 103-10.

[14] Ozturk, A., Ozturk, F., Ozgokce, F., and Keles, A. 1998. "A Research on the Flora of Yuzuncu Yil University Zeve Campus.” In Proceedings of the XIV National Biology Congress, 30-8. (in Turkish)

[15] Kahilogullari, C. 2011. "Investigation of the Usage of Lamiaceae Members Distributed at Zeve Campus of
Yuzuncu Yil University as Food and Medicinal Purposes.” Bachelor thesis, Department of Biology, Faculty of Science, Yuzuncu Yil University, Van, Turkey. (in Turkish)

[16] Langlands, J. P. 1974. "Studies on the Nutritive Value of the Diet Selected by the Grazing Sheep: Part VII, a Note on Hand Plucking as a Technique for Estimating Dietary Composition.” Animal Science 19 (2): 249-52.

[17] Fanchone, A., Boval, M., Lecomte, P. H., and Archimede, H. 2007. "Faecal Indices Based on Near Infrared Spectroscopy to Assess Intake, in Vivo Digestibility and Chemical Composition of the Herbage Ingested by Sheep (Crude Protein, Fibres and Lignin Content).” J. Near Infrared Spectrosc. 15 (2): 107-13.

[18] Marten, G. C., and Barnes, R. F. 1980. "Prediction of Energy Digestibility of Forages with in Vitro Rumen Fermentation and Fungal Enzyme Systems." In Proceedings of the International Workshop on Standardization of Analytical Methodology for Feed.

[19] Tilley, J. M. A., and Terry, R. A. 1963. “A Two-Stage Technique for in Vitro Digestion of Forage.” $J . B r$. Grassl. Soc. 18 (2): 104-11.

[20] Williams, C. H., David, D. H., and Iismaa, O. 1962. “The Determination of Chromic Oxide in Feces Samples by Atomic Absorption Spectrophotometry.” J. Agric. Sci. 59 (3): 381-5.

[21] Della Monica, E. S., and McDowell, P. E. 1971. “Atomic Absorption Spectroscopy versus Alkaline Fusion Method for Determining Chrome in Leather" J. Am. Leather Chemists Assoc. 66: 21-30.

[22] Gudmundsson, O., and Halldorsdottir, K. 1993. "The Use of n-Alkanes as Markers for Determination of Intake and Digestibility of Fish Feed." In Proceedings of EIFAC Workshop on Methodology for Determination of Nutrient Requirements in Fish, 1-6.

[23] Williamson, P. J., Hennessy, D. W., Gogel, B. J., and Barlow, R. 2000. "The Estimation of Faeces Output in Penned Cattle by Controlled Release of Chromium Oxide and the Subsequent Accuracy of Predicting Forage Intake with in Vitro Digestibility.” J. Agri. Sci. 135 (3): 297-304.

[24] Ferreira, L. M. M., Olivan, M., Rodrigues, M. A. M., Osoro, K., Dove, H., and Da Silva, A. D. 2004. "Estimation of Feed Intake by Cattle Using Controlled-Release Capsules Containing n-Alkanes or Chromium Sesquioxide.” J. Agri. Sci. 142 (2): 225-34.

[25] Lopez-Guerrero, I. 2005. "Estimating Forage Mass of Tall Fescue Pastures and Dry Matter Intake and Digestibility of Fescue Forage by Beef Steers.” Ph.D. thesis, Department of Animal and Poultry Sciences, Virginia Polytechnic Institute and State University, Blacksburg, Virginia, USA. 
[26] Dove, H., and Mayes, R. W. 2006. "Protocol for the Analysis of n-Alkanes and Other Plant-Wax Compounds and for Their Use as Markers for Quantifying the Nutrient Supply of Large Mammalian Herbivores.” Nature Protocols 1 (4): 1680-97.

[27] Nakano, M., Yayota, M., and Ohtani, S. 2008. "Evaluation of the Single Pulse Dose Method for Estimating Herbage Intake by Cattle in a Large Scale Free-Ranging System.” Grassland Science 54 (2): 62-8.

[28] Ergun, A., Tuncer, S. D., Colpan, I., Yalcin, S., Yildiz, G., Kucukersan, M. K., Kucukersan, S., Sehu, A., and Sacakli, P. 2011. Animal Nutrition and Nutritional Diseases. Ankara, Turkey: Pozitif Matbaacilik. (in Turkish)

[29] National Research Council (NRC). 1989. Nutrient Requirements of Dairy Cattle, 6th ed.. Washington DC, USA: National Academy Press.

[30] Ishler, V., Heinrichs, J., and Varga, G. 2000. "From Feed to Milk: Understanding Rumen Function.” Extension Circular 422, Penn State Extension, College of Agricultural Sciences, USA. Accessed August 21, 2009. http://www.extension.psu.edu/extension_publication_file.

[31] National Research Council (NRC). 1985. Nutrient Requirements of Sheep, 6th ed.. Washington DC, USA: National Academy Press.

[32] Akkilic, M., and Sürmen, S. 1980. Feed Stuffs and Animal Nutrition Laboratory Book. Ankara, Turkey: A.U. Basimevi. (in Turkish)

[33] Van Soest, P. J., and Robertson, J. B. 1979. "Systems of Analyses for Evaluation of Fibrous Feed.” In Proceedings of the International Workshop on Standardization of Analytical Methodology for Feeds, 49-60.

[34] SAS Institute. 2011. SAS/STAT 9.3: User's Guide. Cary, NC: SAS Publishing.
[35] Karsli, M. A., Deniz, S., Nursoy, H., Denek, N., and Akdeniz, H. 2003. "Determination of the Effects of Vegetation Period on Pasture Quality and Animal Performance.” Turkey J. Vet. Anim. Sci. 27: 117-24. (in Turkish)

[36] Berry, N. R., Scheeder, M. R. L., Sutter, F., Kröber, T. F., and Kreuzer, M. 2000. "The Accuracy of Intake Estimation Based on the Use of Alkane Controlled-Release Capsules and Faeces Grab Sampling in Cows.” Ann. Zootech. 49 (1): 1-3.

[37] Ferret, A., Plaixats, J., Caja, G., Gasa, J., and Prio, P. 1999. "Using Markers to Estimate Apparent Dry Matter Digestibility, Faecal Output and Dry Matter Intake in Dairy Ewes Fed Italian Ryegrass Hay or Alfalfa Hay.” Small Ruminant Research 33 (2): 145-52.

[38] Parker, W. J., McCutcheon, S. N., and Garrick, D. J. 1990. "The Suitability of Chromium Controlled Release Capsules for Estimating Herbage Intakes of Grazing Ruminants.” Index of Livestock Library ab90024. Accessed July 2007. http://www.aaabg.org/livestocklibrary/1990/.

[39] Dove, H., Freer, M., and Foot, J. Z. 2000. "The Nutrition of Grazing Ewes during Pregnancy and Lactation: A Comparison of Alkane-Based and Chromium in Vitro Based Estimates of Herbage Intake.” Australian J. Agric. Res. 51 (6): 765-77.

[40] Momont, P. A., Pruitt, R. J., Emerick, R. J., and Pritchard, R. H. 1994. "Controlled Release Chromic Oxide and Alkaline Peroxide Lignin Marker Methods.” J. Range Manage 47 (6): 418-23.

[41] Elwert, C., Kluth, H., and Rodehutscord, M. 2004. "Effect of Variable Intake of Alfalfa and Wheat on Faecal Alkane Recoveries and Estimates of Roughage Intake in Sheep.” J. Agri. Sci. 142 (2): 213-23. 